\title{
The Role of the Courts in Settling Disputes between the Society and the Government in China
}

Robert Heuser

\section{(2) OpenEdition}

\section{Journals}

Édition électronique

URL : http://journals.openedition.org/chinaperspectives/646

DOI : 10.4000/chinaperspectives.646

ISSN : 1996-4617

Éditeur

Centre d'étude français sur la Chine contemporaine

\section{Édition imprimée}

Date de publication : 1 octobre 2003

ISSN : 2070-3449

Référence électronique

Robert Heuser, "The Role of the Courts in Settling Disputes between the Society and the Government in China », China Perspectives [En ligne], 49 | september-october 2003, mis en ligne le 17 janvier 2007, consulté le 28 octobre 2019. URL : http://journals.openedition.org/chinaperspectives/646 ; DOI : 10.4000/chinaperspectives.646

Ce document a été généré automatiquement le 28 octobre 2019

(C) All rights reserved 


\title{
The Role of the Courts in Settling Disputes between the Society and the Government in China
}

\author{
Robert Heuser
}

1 In the 1990s, the courts, in dealing with administrative cases, reinforced their function of helping to stabilise the economic reforms by consequently reviewing cases concerning infringements of business-autonomy

2 One of the new features in Chinese society brought about by the reform process are the methods of making complaints and settling conflicts. The old ways have by no means disappeared ${ }^{1}$, but new mechanisms have been added and are becoming more prominent. This relates not only to commercial or civil disputes but also to disputes between citizens or firms on the one hand, and governmental agencies on the other.

3 That the law courts are involved in resolving these types of dispute is one of the more surprising phenomena in China today. Not that the people would sue the government in any exaggerated manner: of the around six million cases that the Chinese courts have had to deal with in the last year, only $2 \%$ were related to a conflict between citizens and administrative agencies. ${ }^{2}$ However, the access of persons aggrieved by an administrative decision to the courts has enriched Chinese legal culture with a new ingredient: the traditional and seemingly unchangeable guan guan min (that the officials govern the people) has been supplemented by an attempt, as feeble as it may be, to min gao guan (to let the people sue the officials) ${ }^{3}$.

4 From the very beginning of the conceiving of a system of administrative litigation, the idea of social stability had been pre-eminent. One scholar writing in 1987 ascribed to administrative litigation two functions, both contributing to social stability:

5 - By applying proper legal procedures to the request of a person aggrieved by an administrative decision, the courts may dissipate resentment and discontent through providing more effective remedies than the traditional way of shangfang or laifang-laixin (making complaints and appeals for help by the higher authorities by making visits or sending letters). In other words: The frustration reflected in the saying that "for 
officials to sue the people is just and normal, but there is no effective way for the people to sue the officials" (guan gao min yige zhun, min gao guan meiyou men) could be reduced;

6 - by reviewing and correcting illegal activities of the state agencies by a specialised device outside of the administration the courts may achieve unity of the administrative legal system and protect administrative efficiency. ${ }^{4}$

7 After a few years of limited experimentation the breakthrough for administrative litigation came in 1987 when the Law on Administrative Penalties for Public Security went into force. Since police detention and especially police-imposed fines are widespread, the provision in this law that a person punished who does not agree to this decision is entitled to bring a lawsuit (art. 39), opened the way to judicial review concerning the decisions of that administrative agency most closely related to the everyday life of the people. Still today, "min keyi gao guan" to a great extent means suing the police for illegally imposing administrative sanctions.

8 The importance the Chinese leadership did ascribe to administrative litigation is reflected in the fact that in the legislative history of the PRC it was only the third time that a draft law was published for the general public: the drafts of the 1954 and 1982 constitutions, and in November 1988 the draft of the Administrative Litigation Law (ALL). When the law was finally promulgated in 1989 and went into force in October 1990 the scope of the courts' jurisdiction in administrative matters broadened considerably, and succeeding "Interpretations" of the Supreme Court in 1991 and 1999 continued to further open the gate to the courts. In the following I will first summarise the basic structure or features of the system of administrative litigation as based on the law of 1989 and the Supreme Court interpretations, then deal with the main types of conflicts involved, and finally summarise achievements and problems of the role of the courts in settling administrative disputes.

Scope of administrative litigation

9 The central notion of any system of administrative litigation is the scope of appeal or the scope of the jurisdiction of the courts. The legislator has to answer the question: Who may sue which administrative decision? In continental European countries like France and Germany "access to the administrative courts is accorded in all public law disputes ..." (art. 40 I German Law on Administrative Courts), thus, to all disputes between citizens and the government, as long as the plaintiff claims that the contested administrative act unlawfully infringes his or her rights (art. 113 I). Such a "general clause" has not been established by the Chinese ALL. Instead it takes the approach to single out for review only certain types of "concrete administrative acts" (juti xingzheng xingwei), "concrete" means that the administrative act is directed against a specific person outside the administration. These reviewable administrative acts are enumerated in art. 11, sect. 1 of the ALL; section 2 provides in a catch-all clause that other laws may allow for further types of concrete administrative acts to be sued in the courts. The enumeration contains the following types which also may be said to represent the types of conflicts between society and government which are reviewable in the courts:

10 Administrative penalties (xingzheng chufa) such as detention, fines, revocation of licences or an order to suspend production or business activities; 
11 administrative compulsory measures (xingzheng qiangzhi cuoshi) as restricting personal freedom (as shelter for investigation) or the movement of property (as sealing up or freezing of property);

administrative acts infringing lawful business autonomy (jingying zizhuquan), permitting suits against agencies illegally interfering in enterprise operations and management;

administrative acts denying licences or permits, as e.g. denials of business operating licences;

refusal by an administrative organ to perform its statutory duties, as to protect personal or property rights;

failure to properly pay pensions;

requests by administrative authorities to perform certain obligations to be in breach of the law, which means that all duties imposed must have a legal basis.

17 According to the catch-all clause of art. 11, sect. 2 the courts "may hear other administrative cases as provided for by law." The only example I could find in this regard are the rules concerning notaries promulgated by the Sichuan People's Congress, according to these rules notarial decisions (as for example a certification of a last will) are reviewable by the courts, without respect to the fact that the relevant State Council regulations (Regulations on Notaries) do not contain such a provision.

According to Chinese law these decisions or concrete administrative actions are possible objects of judicial review, and concern the possible conflicts in which the courts may play a role. Since these types of decisions are all related to property rights (caichanquan) and personal rights (renshenquan), other conflicts between citizens and government agencies-not related either to renshenquan nor to caichanquan-cannot be reviewed by the courts.

19 In order to find where the courts cannot play any role in conflicts between society and government one only has to look into the second chapter of the Chinese constitution which deals with "Fundamental Rights and Duties of Citizens", and to compare the rights mentioned there with the enumerations in the ALL. One will find that interference of governmental agencies in the freedom of speech, assembly, publication, association, demonstration and of religious belief as well as in the right to work or the right to get an education are not covered by the shouan fanwei (jurisdiction) of the ALL.

Since the promulgation of this law efforts have been undertaken to make xingzheng susong more relevant to actual conflict resolution, either by clarifying the statutory scope of jurisdiction or by extending the category of persons being capable of becoming a plaintiff and of organisations capable of becoming a defendant.

21 In its Opinion (Yijian) of 1991 Concerning the Execution of the ALL, the Supreme Court made clear that certain police decisions the courts had been reluctant to accept, such as "detention for investigation" (shourong shencha) and "re-education through labour" (laodong jiaoyang) as well as decisions of the birth-planning administration are covered by the jurisdiction clause of the ALL. These Supreme Court Opinions further clarified that decisions of the land administration concerning property rights in land and mineral resources are open to review by the courts.

Through its 1999 Interpretations of the ALL, the Supreme Court has continued to increase the relevance of administrative litigation by defining the capacity both of the 
plaintiff and the defendant. According to the ALL a person has standing to enter an action against an administrative agency as long as he or she claims that the concrete administrative act of this agency "qinfan qi hefa quanyi", "infringed his lawful rights and interests" (art. 2). The Supreme Court clarifies in its Interpretation that also such persons have standing who have "a legal interest" (falüshang de lihaiguanxi) in a concrete administrative act not immediately directed against them. This is, for example, relevant for neighbouring rights (xianglinquan) and for the right to fair competition (gongping jingzhengquan). Concerning the latter one, a court in Fujian province recently decided a case in which the plaintiff sued a city government because it instructed a corporation (owned by the city) to allocate certain raw materials preferentially to certain factories. The court held the opinion that this kind of businesspromotion violated the principle of fair competition and thus the plaintiff's right of business autonomy (jingying zizhuquan). ${ }^{5}$

On the other side, the 1999 Interpretation also clarifies the question of who can become a defendant in administrative litigation. According to the ALL the defendant is the xingzheng jiguan, the administrative agency which has made the concrete administrative act. For a long time it was held that schools and universities cannot be qualified as "xingzheng jiguan". A judgment of a court in the district of Haidian in Peking came to a new understanding, and regarded a university as a proper defendant in administrative litigation. I quote from this judgment ${ }^{6}$ : "In the present situation in China the law confers to certain institutions (shiye danwei) and social associations (shehui tuanti), although they do not qualify as xingzheng jiguan, the right to exercise certain administrative competences. Appeals concerning conflicts resulting from exercising administrative functions are of an administrative and not of a civil nature. Even if the ALL calls xingzheng jiguan as defendants it serves to resolve social conflicts and to maintain social stability when such shiye danwei come to have the capacity to become defendants in administrative litigation." This judgment was incorporated into the Supreme Court Interpretation of 1999 and thus became generally applicable law.

Lower courts have even attempted to break through the statutory framework of jurisdiction in order to protect rights which are neither renshenquan nor caichanquan. In 1997 an intermediate court in Fujian decided a case in which a middle-school teacher appealed against the request of the personnel office (renshiju) of a city to cancel a decision to prematurely retire and re-employ him. The court considered this decision to be in violation of the plaintiff's constitutional right to work (laodongquan) and held that it was itself authorised to review this decision.

A similar case, very problematic in terms of whether the court has jurisdiction, is that of a handicapped student suing a commercial school for infringement of his right to receive an education ${ }^{7}$ : the plaintiff, handicapped by polio, participated in the entrance examinations for vocational schools in Henan. Although he received higher marks than needed for entering the school of his choice, he was not accepted because of his physical condition. The plaintiff, claiming that this was a violation of his right to an education as provided for in the Handicapped Persons' Protection Law, brought an administrative law suit requesting the court to reverse the school's decision. After the court had accepted the case, the school voluntarily reversed its decision and accepted the plaintiff as a student.

Main types of conflict 
Let us look now in a more systematic way at the types of conflict which actually are of concern to the administrative tribunals of the courts.

When the ALL was drafted in the second half of the eighties the discussion about the need for such a law concentrated mainly on three areas of widespread conflict: conflicts concerning administrative sanctions such as fines, detention and revocation of permits; conflicts concerning local cadres at will interfering with agricultural takeover contracts, collecting fees and assigning work; and thirdly conflicts regarding the denial of business operating licences or the slow treatment of applications.

Still today these three areas of conflict represent a great deal of the administrative cases pending in the Chinese courts. Of the roughly 87,000 cases the courts had to deal with in 2000 the share of public security and land administration was about $15 \%$ each, followed by city planning (10\%), industry and commerce administration, tax administration (3\% to $4 \%$ ), and birth planning and health administration about $2 \%{ }^{8}$

Unfortunately, the statistics available from Chinese publications only indicate the origin of the disputed administrative act, they say nothing about the legal nature of these acts. However, it is clear that the overwhelming majority of administrative acts in question are still administrative sanctions. This is reflected by the cases collected in the Renmin fayuan anli xuan series (Selected Cases from the People's Courts), edited by the research office of the Supreme Court since 1992. Looking only to the cases collected in the twelve volumes (27 to 38) for the last three years (1999 to 2001), we find that from the 153 cases more than $30 \%$ concern administrative sanctions ${ }^{9}$, about $12 \%$ are related to land and property rights, and about $10 \%$ relate to the neglect of properly exercising statutory duties as protecting personal or property rights or issuing licences or permits, as denials of business operating licences and even the refusal to issue a permit to travel abroad. Next follow cases concerning infringement of the statutory businessautonomy of industrial enterprises or agricultural take-over contracts. Other cases refer to the request of administrative agencies to fulfil obligations which have no basis in law, e.g. an incorrect tax assessment or compelling peasants to make payments not required by law.

30 Throughout the $1990 \mathrm{~s}^{10}$ the courts, in dealing with administrative cases, have reinforced their function of helping to stabilise the economic reforms by consequently reviewing cases concerning infringements of business-autonomy. In other words, the courts rejected infringements by administrative agencies, mostly the Gongshang guanliju (Agency for the Administration of Industry and Commerce), of the rights of enterprises to make decisions on production, management, investment, marketing, etc. By their review work the courts claim to be assisting the large and medium state enterprises in transforming their "business mechanism", in other words, in helping them to adjust to market behaviour.

1 The courts further contributed to strengthening market structures by stopping behaviours like establishing cartels (luan she ka) or arbitrary imposing of fines and fees (luan fakuan, luan shoufei) on enterprises. In 1994, the Agency for the Administration of Industry and Commerce of Qingdao lost a suit to 472 geti gongshanghu-plaintiffs who fought successfully against the decision of the gongshangju to strip them of their business licences (jingying zhizhao) ${ }^{11}$.

Since the mid-1990s, cases concerning city construction or city planning have grown strongly. Also, cases concerning arbitrary infringement of personal freedoms through 
administrative detention, detention for interrogation and re-education through labour are growing in number by an average of $10 \%$ to $20 \%$ annually.

Recently, cases concerning social insurance payments and minimum living fees have become more prominent ${ }^{12}$.

More spectacular, however, are cases concerning the relationship between students and colleges as well as between teachers and school administrations. Here, attempts are being made to overcome the limits of the jurisdiction clause of art. 11 of the ALL, as I illustrated by the cases of the teacher and of the handicapped student.

A special kind of litigation relates to administrative torts based on the State Liability Law (guojia peichang fa) of 1994. Plaintiffs who suffer harm as a result of improper administrative actions have the right to claim compensation in tort. If damages are awarded, they are to be paid from the public funds of the administrative organs involved, possibly these organs can seek indemnification from the official at fault if he acted by intention or with gross negligence. The State Liability Law adds to the authority of the courts over administration organs. Many cases aim at compensation because of illegal "detention for investigation" or "re-education through labour", at an illegal revocation of a licence or an order to suspend production, at illegal infringements of business autonomy or at compensating damages suffered because an agency did not fulfil its statutory duty to protect the property or personal rights of a plaintiff. So, for instance, in May 1998 a Shanghai court compensated the bereaved of a person in police custody (zhi'an juliu) who died through illness because he did not receive medical treatment in due time. ${ }^{13}$ The compensation paid in administrative torts cases grew from 24 million yuan in 1992 to 170 million yuan in 1994. Although this seems to reflect a healthy development of the courts' control function, there are many problems with the execution of the State Liability Law, as I will show later on.

Whereas we can say concerning illegal (weifa) actions of administrative agencies that the State Liability Law makes available a legal system for attaining compensation, this is not the case when damage has been caused by an agency acting legally. How to deal, for instance, with the damages suffered by peasants and enterprises in the Jiujiang area when, during the 1998 Changjiang flood disaster the government decided to drain off the water, they had to accept the flooding of villages and small towns "in order to save Wuhan"? The State Liability Law does not apply. It also does not apply in a case where a city government, emphasising aims of environmental protection, decided under a new local regulation (difangxing fagui) to close and afforest a quarry in which several companies had been awarded long-term exploitation licences by the city. Compensating damages caused by this kind of non-illegal act is an open question. Some authors suggest supplementing the State Liability Law accordingly, while others are more in line with legal doctrine when requesting the promulgation of an extra State Compensation Law (guojia buchang fa).

Problems and achievements

37 To summarise the problems and achievements of the courts in dealing with citizengovernment-disputes:

The Chinese novelist Ha Jin has the protagonist of his novel In the Pond (1998) express his hope, that "though it was said that under heaven all crows are black, there had to be a place where he could let out his discontent and find justice." Do the Chinese People's Courts provide this role the man "in the pond" is dreaming of? 

to 90,000 cases annually ${ }^{14}$ seems sufficient to justify the conclusion that administrative litigation as a legal instrument to provide judicial relief is not very successful. The reasons are manifold. First, there are the three "being afraids" (sange pa): Citizens and firms do not dare to sue, because they are afraid of retaliation by the agency sued; agencies are not willing to become defendants because they are afraid to lose authority, and courts hesitate to accept cases because they are afraid to spoil their relations with the government. These fears have their roots not so much in any old-fashioned psychology inherited from the past, but in the Chinese constitution which does not accept a separation of power. The courts are therefore not only not independent from the executive but in practice very dependent, because they are funded by the government at the respective level and not directly by the central budget of the Supreme Court or the Ministry of Justice.

secondly, more concrete problems of administrative litigation have to do with its normative structure as such. For instance, the problem of distinguishing between concrete administrative acts which are reviewable and abstract administrative acts which are not. This often means an escape for administrative agencies: they use the form of an abstract act, which in fact is directed to an ascertainable group of persons, therefore in substance a concrete act; however, courts, looking to the form, are reluctant to accept such cases. Here lies the main reason why the courts play only a very weak role in one of the most urgent problems in the countryside: the tax-burden of the peasants. Cases are rare because the local governments impose taxes or assign works (tanpai) on the basis of legal documents which the courts regard as "abstract administrative acts", and therefore do not accept any lawsuits in these matters.

This problem also has to do with the insufficiency of substantial administrative law. The nature of the concrete administrative act has not been defined by law. There is no clear understanding of what could be defined as a general order (Allgemeinverfügung), which could be sued in court, and a normative act against which an action could not be brought. This in turn is related to legal doctrine which has not yet elaborated reliable criteria to differentiate concrete administrative acts on the one hand, generally binding acts, internal acts, and acts of a non-compulsory nature on the other.

The main defect in dealing with administrative tort cases is also due to the normative structure of the relevant law. According to the State Liability Law (see also § 67 II ALL) compensation claims must first be arbitrated by the administrative authority and only then can they be taken to court. This is contrary to most other administrative cases (and of course any civil claim for compensation) which can be taken straight to court.

Considering the results of administrative litigation we come across another problem. During the 1990s the tendency that the plaintiffs withdraw the lawsuit became more and more obvious. Roughly spoken, $30 \%$ of the judgments maintained the administrative decision, in $15 \%$ it was revoked, and about half of lawsuits had been withdrawn by the plaintiff and in some years even up to $60 \%$ did so. The reasons for this may be a change of mind in the person of the plaintiff, pressure and even intimidation by the defendant, suggestion of the court in order to please the defendant, but also the strategy of a plaintiff himself to bring a suit with the implied intention to induce the defendant to agree to an out-of-court settlement. Siliao or "private settlements" of administrative disputes seem to be very common. They are often perceived as more favourable for the plaintiff, since the conflict may be settled fast

China Perspectives, 49 | september-october 2003 
and, above all, the plaintiff may spare a good deal of trouble with the agency in the future. that the role of the courts in settling administrative conflicts can be ignored. In the contrary, in spite of all obstacles, this role has become more prominent during the last few years. Some Chinese research undertaken two years ago in Jiangsu ${ }^{15}$ found that the influence of the courts became more important in the difficult field of birth planning. Litigation here relates mostly to administrative penalties imposed without legal basis or ignoring any legal procedure. The courts have restrained the arbitrary application of excessive fines, interference in personal freedom, confiscation of property and of completely extra-legal sanctions like the brutal demolishing of the houses of couples having violated birth-control regulations. Besides sanctions, the refusal to issue a "OneChild-Certificate" (dusheng zi-nü zheng) became an object in birth-planning related litigation.

Concerning the protection of the autonomy of business management the courts have continuously quashed decisions of local governments interfering in the freedom of contract, in the rights of enterprises to market their products, to decide about their investments, to fuse with other enterprises or to hire or keep their managers. Here and in other citizen-government relations xingzheng susong has proved to be an effective instrument in providing judicial relief to citizens and enterprises. With the improvement of the quality of the court personnel the further development of the scope of jurisdiction, a stronger estimation of judicial independence by the government and finally by constitutional reforms which will be a main task of the next decade, the institution of judicial review of administrative action will gradually consolidate. Besides this, the role of the court is not only reflected by actual treatment of cases but also by the influence they extend to the work of administrative agencies because of the sheer possibility that "min gao guan you men", "the citizens may get a place to find justice". Therefore it is sometimes mentioned in Chinese studies that administrative litigation happens more often in underdeveloped areas (like Henan and Xibu), whereas in more advanced areas administrative agencies have become more used to doing their work according to law. The days seem to be over when the law was perceived only as a means to control the people. Although it is time to conclude that what actually has been achieved is something of a drop in the bucket, nevertheless the courts are looked at more and more as the citizens' most necessary and most likely protectors.

\section{NOTES}

1. See e.g. Stanley Lubman, Bird in a Cage, Stanford University Press, 1999, 447 pp., and Kevin J. O'Brien and Lianjiang Li, "The Politics of Lodging Complaints in Rural China", The China Quarterly, n 143, september 1995, p. 756.

2. As compared to nearly $25 \%$ in Germany (including cases concerning fines [Bußgeldverfahren], financial and social litigation.

China Perspectives, 49 | september-october 2003 
3. See Pitman B. Potter, "The administrative litigation law of the PRC: Judicial review and bureaucratic reform", in Pitman B. Potter (dir.,), Domestic Law Reforms in Post-Mao China, New York, M. E. Sharpe, 1994, pp. 270-304; and Minxin Pei, "Citizens v.

Mandarins: Administrative Litigation in China", The China Quarterly, No. 152, 1997, pp. 832-862.

4. Yu An, Shehu anding yu xingzheng susong (Social Stability and Administrative Litigation), Fazhibao, September 16th 1987.

5. Bulletin of the Supreme Court 2001, S. $211 \mathrm{ff}$.

6. Bulletin of the Supreme Court 1999, Nr. 4, S. 141.

7. Supreme People's Court Legal Research Section (ed.), "Renmin fayuan anlixuan"

(Collection of Cases of People's Courts), Vol. 25 (1998), No. 65.

8. Zhongguo falü nianjian 2001, Peking; Falü chubanshe, 2001, at 1258.

9. The agencies involved are not only the police (gong'anju), but also agencies for industry and commerce, public health, birth planning, traffic, environmental protection, etc.

10. For the following Falü nianjian 1991, p. 21; 1993, p. 84; 1994, p. 100; 1995, p. 96; 2001, p. 165.

11. Falü nianjian 1995 , p. 96.

12. Falü nianjian 2001, p. 165.

13. Renmin fayuan anlixuan, Vol. 36 , No. 64 .

14. Less than the number of administrative cases the courts of the German State of North-Rhine Westphalia have to deal with.

15. Fang Ning, Sun Jing et al., “Lixing de huhuan: Zhongguo 'xingzheng susongfa' shishi xiankuang diaocha baogao" (The call of reason: Research report concerning the circumstances in implementing the "Administrative Litigation Law"), in: Dongwei faxue 2001, p. $301 \mathrm{ff}$. 